\title{
Role of the Supreme Court in the Constitutional and Political Development of Pakistan: History and Prospects
}

\section{Comparative Study of Begum Nusrat Bhutto (1977) and Syed Zafar Ali Shah Case (2000)}

\author{
Fayyaz Ahmad Hussain ${ }^{1} \&$ Abdul Basit Khan ${ }^{2}$ \\ ${ }^{1}$ Former Faculty Member, Department of Political Science \& International Relations, Bahauddin Zakariya \\ University (BZU), Multan, Pakistan \\ ${ }^{2}$ Department of Political Science \& International Relations, Government College University, Faisalabad, Pakistan. \\ Correspondence: Abdul Basit Khan, Lecturer, Department of Political Science \& International Relations, \\ Government College University, Faisalabad, Pakistan. Tel: 92-300-609-0344. E-mail: basitniazi@yahoo.com
}

Received: April 3, 2012 Accepted: April 19, 2012 Online Published: May 11, 2012

doi:10.5539/jpl.v5n2p82 URL: http://dx.doi.org/10.5539/jpl.v5n2p82

\begin{abstract}
Pakistan has undergone the imposition of Martial Law for quite a few times. On these occasions, the then existing constitutions were either abrogated or held in abeyance and were partially applicable. Invariably these extra constitutional steps were challenged in the courts of law. The historical background of these cases had similarities and dissimilarities; nevertheless irrespective of similarities the courts of law examined these cases in somewhat different manner and from variant angles. Irrespective of the nature of their verdicts in these cases, the same had very serious impact and significant repercussions on the style and development of the political system in Pakistan. The aim of this study is to compare and contrast the background of the imposition of Martial Law in 1977 and military takeover of 1999 alongwith the verdicts of the superior judiciary when the same were challenged and brought before the courts of law.
\end{abstract}

Keywords: martial law, PCO, constitution, oath, superior judiciary, verdict

\section{Introduction}

Since its establishment in 1947, Pakistan has witnessed quite a few episodes of military takeovers when various Martial Laws were imposed and the then existing Constitutions were abrogated. During these intervals the country was governed by the Armed Forces for a period as long as almost half of its life. Invariably every time the imposition of Martial Law was challenged in the Superior Courts and the Courts in each case dealt with the issue in somewhat different manner. Whatever was the verdict of the Courts in these cases, it had very significant impact and repercussions on the political and constitutional development of Pakistan.

In this study we have selected two cases titled "Begum Nusrat Bhutto vs. Chief of the Army Staff and Federation of Pakistan” (1977) and "Syed Zafar Ali Shah vs. General Parvaiz Musharraf, Chief Executive of Pakistan” (2000). In these cases the Martial Law imposed by General Mohammad Ziaul Haq and the military takeover (through an undeclared Martial Law) by General Parvaiz Musharraf were challenged. We have selected these cases as they have a number of similarities notwithstanding some dissimilarity related to the pretext or justification for takeover can also be found. In both the cases the Armed Forces intervened in somewhat different circumstances and in different manner whereas there are similarities related to the verdict and judgment of the Courts. Invariably on these occasions including the two under investigation, the judges of the Superior Courts took fresh oaths under Provisional Constitutional Orders (PCOs) in the manner required by the military commander. The Courts did not confine to the provision of legitimacy and justification to the extra constitutional steps taken by the Army Chiefs rather going many steps ahead granting them the power to amend the Constitution arbitrarily. The scope of this study is to examine the details of the circumstances existing in the country at the verge of each of the two episodes, compare and contrast the proceedings and verdicts of the Superior Courts. The utility and significance of this study can hardly be underestimated because at the time (2011) it is being conducted, judicial activism and attempts of the Superior Courts to assume a supervisory and superior role over other institutions have still to settle down; which in 
its turn shall again have serious impact and significant repercussions on the future style and performance of the political system in Pakistan. In August-September 2011, the suo moto action regarding targeted killings in Karachi, which exhibit somewhat a picture of civil war, taken by the Chief Justice of Pakistan prima facie appears to be a pre-emptive step to control such a situation which in the past had resulted in the apparent failure of the governmental writ consequently facilitating the imposition of Martial Law. The study shall give the reader the opportunity to understand the role of the Superior Courts before 2009 (which was extremely submissive) and compare with their role under judicial activism (2009 onwards). In the following pages we will discuss the historical background pertaining to these two cases which is essential and shall be helpful to analyze the same.

\section{Begum Nusrat Bhutto vs. Chief of the Army Staff}

\subsection{Agitation against Bhutto Government}

Before the imposition of the Martial Law in 1977, Pakistan was facing quite a serious condition of law and order. The countrywide agitation including the use of violence and show of street power had totally undermined the minimum level of the governmental writ throughout the mainland and had disturbed the daily life of the citizens. The situation in the largest cities of Karachi, Lahore, Multan and Peshawar was extremely explosive. Armed Forces were called to maintain law and order but to no avail because at some places they received substantial resistance hence were ineffective whereas in some other places especially in the Punjab, the personnel of the Armed Forces were either reluctant to combat with the civilians or totally refused to fight against their own people (Hussain, 1989: passim). It would be worth-mentioning that this situation was not product of a simple or single phenomenon rather was creation and outcome of complexities. Zulfiqar Ali Bhutto, the then Prime Minister, had time and again alleged that the United States of America was involved in the creation of the said turmoil. He believed that the Pakistan National Alliance (PNA), constituted by nine political parties having nothing in common but the animosity against him, was sponsored by the US Administration. Leaving alone that to what extent Bhutto was right in blaming the US and the PNA for the turmoil, but it was beyond doubt that the PNA was combination of odds which could not be explained in any term of logic except to agree with Bhutto's contention that they were working under foreign command. The PNA consisted of the Marxist-Leninist party of the left i.e. National Awami Party of Khan Abdul Wali Khan on the one hand and the fundamentalist religious parties like Jamaat-i-Islami, Jamiat-ul-Ulema-i-Islam and Jamiat-ul-Ulema-i-Pakistan on the other; while Tehreek-e-Istiqlal, an anti-right progressive party led by Air Marshal Asghar Khan, was another constituent of the alliance. During anti-Ayub agitation, Asghar Khan advocating progressive manifesto had once joined hands with Bhutto and was known to be his logical ally whereas it is worth-noting that during PNA's election campaign and post-election agitation he appeared to be the most vocal opponent of Bhutto. Elections for the National Assembly and the four Provincial Assemblies were scheduled to be held on $7^{\text {th }}$ and $10^{\text {th }}$ of March 1977 respectively and according to the results of the elections for the National Assembly, declared by the Election Commission of Pakistan, the PNA could not win a considerable number of seats in the National Assembly. The polling for the elections of four Provincial Assemblies scheduled on the $10^{\text {th }}$ of March was boycotted by the Alliance alleging that for sweeping all the constituencies, Bhutto had widely rigged the elections to the National Assembly.

\subsection{Involvement of the Army}

The situation was not that simple as it seemed. Lawrence Ziring (1998) observes that within the army especially among the lesser ranks there was a common feeling of resentment against Bhutto's questionable and arrogant behavior as well as policies of his government. They believed that if allowed to continue he would destroy the remaining Pakistan. Ziring further observes that on this point there was no disagreement among the principal commanders of the army who were very clear about remaining loyal to Bhutto or breaking with him (Ziring, 1998: 419). He writes

“These were not the idle thoughts of the military's higher echelon, but the sentiments of a solid portion of the army's unit and field officers. As early as December 1976, no longer able to endure Bhutto's behavior, field and junior officers of the Pakistan Army plotted his overthrow. It would take the elections of March 1977 and the resulting aftermath to their planning to the point of execution. It would also take substantial pressure to convince General Zia to lead the coup. Zia was not the strategist in the overthrow of Zulfikar Ali Bhutto, but he was made an instrument. Zia was faced with a win-lose situation and, in order to preserve the unity of the army as well as his command, he yielded to those younger majors and colonels who had earlier concluded it was either them or Bhutto.” (Ziring, 1998: 420)

“Time, however, had run out. The younger officers had 'convinced' their senior commanders that the moment for action had arrived. Bhutto would be denied the use of the instruments of official 
violence and would no longer be permitted to silence his opposition. The Prime Minister, they concluded, would sacrifice the country, much as he had sacrificed East Pakistan. Truly believing that 'heads would roll' if Bhutto was allowed to remain in power, the majors and colonels forced Zia's hand. The generals would either go along with the coup or they, too, would be victims in the unfolding drama. Zia's choice lay in preserving the integrity of the army or saving Bhutto. In the end, he chose the army.” (Ziring, 1998: 422)

Ziring's (1998) statement is more than reliable because he is not a simple researcher or book-writer rather he is part of the think-tank which dominate US policy making and implementation. Moreover, he has full access to all sensitive and secret documents of both US and Pakistan's administrations.

One can very well infer from Ziring's statement that the Armed Forces had already planned to overthrow Bhutto well before July 1977 hence could be instrumental in managing to paint a picture of such elections which appeared to be widely rigged. Bhutto might have lost some of his popularity as a leader but it was proved by later happenings that he had not become that unpopular as projected by PNA and the Armed Forces.

\subsection{Imposition of Martial Law by Zia}

On $5^{\text {th }}$ of July 1977, Zia imposed Martial Law throughout Pakistan. Bhutto was dismissed and taken in custody. Unlike Ayub (1958) and Yahya (1969) he declared the then existing Constitution of 1973 as held in abeyance. He immediately met Justice Yaqoob Ali, the Chief Justice of Pakistan because after the takeover the foremost task for Zia was to seek legitimacy for his extra constitutional steps. Chief Justices of the four High Courts were appointed as acting Governors of their respective provinces who readily accepted the said assignment. In order to further appease the judiciary, the writ jurisdiction of the Courts was restored on $7^{\text {th }}$ of July, 1977 i.e. only two days after its withdrawal through Laws (Continuance in Force) Order 1977 (Note 1).

\subsection{Election Campaign and Detention of Bhutto}

Zia announced that the general elections would be held on October 18, 1977. Accordingly all the political parties including Bhutto's PPP started their campaign. Contrary to the opinion and belief of the Zia regime and the PNA, Bhutto's public meetings were fetching huge gatherings. Everywhere he received very warm welcome from the people who had been anxiously waiting for quite long just only to have a glimpse of him. Hamid Khan (2009) )observes

"The PNA realized that Bhutto was not yet undone, but was a potential danger as long as the elections loomed large on the horizon. Meanwhile, the martial law government felt constrained to stop Bhutto's eventual return to power. It seemed that elections could only help Bhutto. The only way out for the martial law regime was to bar the PPP leader from participating in the elections.” (Khan, 2009: 325)

On $17^{\text {th }}$ September 1977, Bhutto and ten other members of his party were detained under a Martial Law regulation issued by Zia regime. After that Nusrat Bhutto took over the job and started addressing public meetings which were fetching even more people than before. This was rather a cumbersome position for Zia and Bhutto's opposition.

"On 30 September, the PNA chief, Mufti Mahmood, also urged accountability before the polls. This meant that the PNA had become demoralized by seeing that the PPP, now led by Nusrat Bhutto, was attracting large crowds in their election rallies. The PNA leadership rushed into the arms of Zia and the military junta seeking the postponement of elections.” (Khan, 2009: 326)

On $20^{\text {th }}$ September 1977, the detention of Z.A. Bhutto and his associates was challenged by Begum Nusrat Bhutto through a writ petition filed in the Supreme Court of Pakistan. In the petition, the validity and legality of the regime was challenged alleging that the detentions were aimed at preventing the PPP's participation in the election. In exercise of the original jurisdiction of the Court, Chief Justice Yaqoob Ali admitted the said petition and ordered immediate shifting of the detenus from Lahore to Rawalpindi (which received no compliance from the regime). The $25^{\text {th }}$ instant was fixed for the next hearing.

\subsection{The Reconstitution of the Supreme Court}

The admission of the petition assured Zia that the Chief Justice was not going to do the needful hence he was prompt to amend the Constitution of 1973 arbitrarily through CMLA's Order Number 6 of 1977 issued on September 22, 1977 (Note 2). As a consequence of the said amendment, the Fifth and the Sixth Amendments were withdrawn from the Constitution. By virtue of the Sixth Amendment, Yaqoob Ali Khan, even after attaining the age of superannuation fixed for the judge of the Supreme Court, was allowed to continue and complete five years 
term as the Chief Justice of Pakistan. After the withdrawal of the Sixth Amendment, Justice Yaqoob Ali stood retired and the Supreme Court was left without a Chief Justice. The Martial Law administration reconstituted the Supreme Court and Justice Anwar-ul-Haq assumed the office of the Chief Justice of Pakistan. The Court succumbed to the said exercise of authority by the Chief Martial Law Administrator thus establishing superiority of the latter over the former. By virtue of that act, even prior to the proceedings and decision of the Nusrat Bhutto case, the Supreme Court of Pakistan had not only accorded legitimacy to the Martial Law regime of Ziaul Haq rather it had acknowledged and recognized its inherent authority to amend the Constitution. Hamid Khan observed that obviously the Supreme Court reconstituted by virtue of the said amendment in the Constitution of 1973, had right from the beginning accepted the lawful authority of the regime and recognized it as the new law-giver. He concluded

"How could a court which accepts such change and re-constitution of the law later turn around to state that the law maker had no power to make such a law?”(Khan, 2009: 326)

Earlier, on $7^{\text {th }}$ of July 1977, Zia regime had issued High Court Judges (Oath of Office) Order, 1977, which required the judges of High Courts to take a new oath in amended form (Note 3). However no time limit was imposed to take such oath. Except a few judges of the Lahore High Court, all the judges of the four High Courts had already taken the new oath when, on $22^{\text {nd }}$ of September 1977, the said order was amended by the regime through High Court Judges (Oath of Office) (Amendment) Order, 1977, requiring the remaining judges of the High Courts to take the new oath within twenty-four hours of the issuance of the order failing which they would cease to hold their offices (Note 4). On the same day, a similar order was issued requiring the judges of the Supreme Court to take new oath in the same form as taken by the judges of the High Courts. All the Judges including the new Chief Justice of the Supreme Court took oath in compliance with the said orders (Note 5).

\subsection{The Court and the Judgments}

After the Supreme Court was reconstituted in the manner suited to the Martial Law regime, the petition was heard by a nine-judge (a full-court) Bench headed by Chief Justice Sheikh Anwar-ul-Haq. On fourth day of the hearing i.e. October $1^{\text {st }} 1977$, the regime invalidated the principal ground for the case by postponing the national elections for an indefinite period. All political activities were also banned (Note 6). The Court met for twenty-one days, heard Mr. Z.A. Bhutto and Mr. Abdul Hafiz Pirzada in person and received written statements from them and Mr. Mumtaz Ali Bhutto in order to avoid charges of incompleteness of the proceedings as suffered by Dosso's case (Note 7).

The leading judgment was written by the Chief Justice who held that the petition was not maintainable and passed order of its dismissal. Justice Muhammad Haleem and Justice G. Safdar Shah endorsed the judgment authored by the Chief Justice. Justice Waheeduddin Ahmad, Justice Afzal Cheema, Justice Muhammad Akram, Justice Dorab Patel, Justice Nasim Hassan Shah and Justice Qaiser Khan wrote separate judgments because they agreed with the judgment written by the Chief Justice only to the extent of dismissal of the petition however, for passing the said order, they had reasons, arguments and grounds different than those recorded by the Chief Justice in the leading judgment.

\subsubsection{Leading Judgment by Anwarul Haq (Chief Justice)}

The Chief Justice recorded the circumstances prevailing in the country between $7^{\text {th }}$ March and $5^{\text {th }}$ July 1977 in detail and held that there was a serious political crisis in the country leading to a break-down of the constitutional machinery for which the Constitution provided no solution. Before applying the doctrine of necessity in the instant case, he referred to the essence of the doctrine as expounded by renowned Islamic analysts and its application by the Courts of other countries including the Federal Court (as it was named before the promulgation of the 1956 Constitution) and the Supreme Court of Pakistan in the Reference sent by the Governor-General of Pakistan (Note 8) and Asma Jilani case respectively (Note 9). He affirmed that the situation prevailing in the country during the period mentioned above was a mature case for invoking the law of State necessity wherein

"the Armed Forces of Pakistan, headed by the Chief of Staff of the Pakistan Army, General Muhammad Ziaul Haq intervened to save the country from further chaos and bloodshed, to safeguard its integrity and sovereignty, and to separate the warring factions which had brought the country to the brink of disaster. It was undoubtedly an extra-constitutional step, but obviously dictated by the highest consideration of State necessity and welfare of the people.” (Note 10)

He ruled that the said step was thus valid and in accordance with the parameters of the doctrine of necessity. While defining the extent and scope of the powers exercised by the Chief Martial Law Administrator, the learned Judge 
remarked that the relevant factor to understand the true nature of the change was the motive of the Chief Martial Law Administrator as declared by him on $5^{\text {th }}$ of July, 1977. He held that various definitions of Martial Law offered by some of the renowned jurists could not be applied in the instant case as the 1973 Constitution still remained the supreme law of the land wherein the military take-over was followed by the continuance of the civilian President in office under the Constitution and the superior judiciary was still functioning subject to certain limitations upon it as spelt out by the Laws (Continuance in Force) Order of 1977.

The learned Chief Justice ruled that the Chief Martial Law Administrator, was entitled to perform all such acts and promulgate all legislative measures which consistently had been recognized by the judicial authorities as falling within the scope of the law of necessity and which entitlement, inter alia, included all acts or legislative measures which were in accordance with, or which could have been done under the 1973 Constitution, including the power to amend it.

The learned Chief Justice further held that to achieve his declared objective of promoting the good of the people, the Chief Martial Law Administrator was entitled to perform any act and for that purpose Presidential Orders, Ordinances, Martial Law Regulations or Orders might be used; which if challenged might be reviewed by the Court in the light of the principles underlying the law of necessity. The said power of judicial review might be exercised by the Court notwithstanding anything to the contrary contained by any Presidential Order, Ordinance or Martial Law Regulation/Order.

The learned judge noted that the scheduled elections were postponed till the completion of accountability process of the holders of public offices. It was elaborated by the learned Attorney-General that a period of six months was required for that purpose and thereafter it would be possible to hold the elections within two months. The learned Chief Justice endorsed the contention of the regime as validly based on the doctrine of State necessity and held that it was inappropriate to issue any direction for the announcement of a definite time-table in that regard. He mentioned that the Chief Martial Law Administrator in his speech of July 5, 1977, had declared that the period of constitutional deviation shall be of as short duration as possible. The learned judge stated in clear terms that the said extra-constitutional step was validated by the Court only on the basis of that solemn pledge. According to him, the attribution of any other intention to the Chief Martial Law Administrator or the insinuation that he did not intend to restore democratic institutions as provided under the 1973 Constitution, would be highly unfair and uncharitable. He expected that the said pledge would be redeemed by the Chief Martial Law Administrator because in its nature the same was actually a mandate from the people of Pakistan, who had, by and large, willingly accepted his administration as the interim government of Pakistan.

The learned Chief Justice ruled that by virtue of clause (3) of Article 2 of the Laws (Continuance in Force) Order, 1977, the Fundamental Rights stood validly suspended since the $5^{\text {th }}$ of July, 1977 hence the petition was not maintainable.

\subsubsection{Waheeduddin Ahmad (Judge)}

Justice Waheeduddin Ahmad added that he was a party to the judgment in Asma Jilani case, and in his view, the principles laid down in the said case did not apply to the facts of the instant case. According to him, the circumstances of the instant case demanded the principles enunciated by the Federal Court in the Reference by His Excellency, the Governor-General be applied.

\subsubsection{Afzal Cheema (Judge)}

Justice Cheema added that Kelsen's Theory applied by the Court in State vs. Dosso was in conflict with the Divine Law of Islam because it was man-made and not based upon morality; whereas unlike a pure theory of law, the Islamic principles were subjectively centered around morality and aimed at the establishment of an orderly and peaceful moral society placing the security, safety and welfare of the people above everything else. While referring to the relevance of the doctrine of necessity in the instant case he relied solely upon Islamic Jurisprudence and quoted a large number of Quranic verses and traditions of the Holy Prophet (SAW). The learned judge concluded that the recognition and application of the said doctrine in collective and individual perspectives had its origin in Islamic Jurisprudence rather than its western counterpart. He emphasized that the doctrine of State necessity was an extension of the doctrine of individual necessity contemplated by Islam which could be applied with equal force in graver situations of national importance.

In the end of his judgment, the learned judge noted that country wide protest of the people against the government of Mr. Zulfiqar Ali Bhutto had created a situation of a complete breakdown of law and order for which there was no solution provided by the Constitution. He ruled that the doctrine of necessity had, therefore, been rightly 
resorted to by the Chief of the Army Staff on $5^{\text {th }}$ of July, 1977 when he took over administration of the country and imposed Martial Law.

\subsubsection{Muhammad Akram (Judge)}

The learned judge traced the roots of the Kelsen's theory applied in State vs. Dosso and declared that the Kelsenian theory was rightly rejected by the Court in Asma Jilani case. In his view, to provide the solution to the post-revolution legal problems, application of the said theory by Chief Justice Munir in State vs. Dosso, was based upon self-deception.

While dealing with the proclamation of Martial Law and its recognition by the Courts, he declared that the Courts were not obliged to recognize any act of overthrowing the legitimate government and the consequent proclamation of Martial Law as valid. However validation of such act by the Courts would result in providing the legality to the new regime and if the same was declared invalid then the judges could not expect to retain their offices for long.

In the light of the above, the learned judge held that the peculiar facts and circumstances of the instant case demanded application of the law of State necessity which was rightly invoked by the Chief Justice.

2.6.5 Dorab Patel (Judge)

Justice Dorab Patel differed with the Chief Justice regarding the application of the doctrine of necessity in the instant case. Referring to the principles of the said doctrine as laid down by the Federal Court in the Reference by His Excellency the Governor-General, he ruled that to resolve the impasse created by the constitutional break-down, the same principles would have to be followed.

\subsubsection{Qaiser Khan (Judge)}

Justice Qaiser Khan noted that notwithstanding there was no provision of the second oath in the Constitution of 1973, the judges of the Superior Courts when required to take a second oath (having no mention of the Constitution of 1973) under the President's post-Proclamation Order 9 of 1977 or to quit, had preferred for the first option; hence the de facto existence of the new Legal Order was conceded by the judiciary through the said new oath. He added that the moment when the Constitution of 1973 was held in abeyance, the Courts had ceased to exist which got revived not by virtue of the old Constitution of 1973 but only by the force of Laws (Continuance in Force) Order of 1977 which was an effective new Legal Order and had suppressed the old Legal Order (Constitution) for the time being. The learned judge raised the question that if after the Proclamation, the Chief Martial Law Administrator had not issued the Laws (Continuance in Force) Order of 1977 and had started ruling the country by decrees through his officers then where would have been that Court and what jurisdiction then it would have had? He concluded that the judicial power needed to be exercised within the framework prescribed by the new Legal Order because the Courts had no other norm available to test the validity of any action and answer any legal questions raised thereof because the actions of the de facto government and the acts of the Martial Law Authority could only be tested under the Old Legal Order when the said government and the authority ceased to exist and the said Legal Order was revived. Hence the Court had no jurisdiction to entertain and adjudicate upon the petition.

Justice Qaisar Khan declined to agree with the Chief Justice regarding the nature and scope of the doctrine of necessity. He held that the said doctrine could not be applied in the instant case as it was not an independent legal system but an integral part of the framework of a total Legal Order and could be resorted only to deal with a situation for which there was no provision in the Constitution. That doctrine had therefore been rightly resorted to by the Chief of the Army Staff on $5^{\text {th }}$ of July, 1977. After the suspension of the 1973 Constitution, the said doctrine automatically got suspended with it which automatically reappeared, but within the framework of a new Legal Order, proclaimed under the Laws (Continuance in Force) Order of 1977. He added that if no provision could be found, for dealing with a future situation, under the said new Legal Order, only then the doctrine of necessity could again be resorted to.

The learned judge declined to entertain the contention of the Chief Justice that the pledges made by the Chief Martial Law Administrator through his various public statements must be trusted. He ruled that the said pledges being not enforceable under any law were not concern of the Court because it was a matter only between the Chief Martial Law Administrator and the people of Pakistan. Addressing to the issues of holding general election within prescribed time limit and restoring democracy in the country, he ruled that it was not within the scope and jurisdiction of the Court to direct the Chief Martial Law Administrator to do or not to do such and such things within such and such time. 
2.6.7 Muhammad Haleem (Judge) Agreed with the Chief Justice.

2.6.8 G. Safdar Shah (Judge) Agreed with the Chief Justice.

\subsubsection{Dr. Nasim Hassan Shah (Judge)}

Justice Nasim Hassan Shah added that the judgments in Dosso and Asma Jilani cases were irrelevant hence inapplicable to the substantially different situation of the instant case. In those cases the intention was to suppress as well as replace the then existing Constitutions with a new Legal Order; whereas in the instant case, the existing Constitution was not abrogated rather merely held in abeyance and to be revived after holding free and fair elections.

He held that the said intervention could not be declared as lawful but could be justified on the basis of the doctrine of "necessity" in terms of which any act that was otherwise unlawful could be rendered as lawful.

Keeping in view the circumstances prevailing in the country on and immediately before $5^{\text {th }}$ of July, 1977, he declared that the provisions of the law of necessity were rightly invoked by the Chief Martial Law Administrator hence the action taken by him was valid.

\section{Syed Zafar Ali Shah vs. General Parvaiz Musharraf, the Chief Executive of Pakistan}

\subsection{Background}

In 1993, Ghulam Ishaq Khan, after a long political turmoil and tussle between him and Prime Minister Nawaz Sharif, dissolved the Parliament and dismissed the government. When the order of the President was challenged in the Supreme Court of Pakistan, the Court set aside the said order and reinstated the government (Note 11).

Though the said revival of the government did not suit the plan of the establishment and various stakeholders of the power echelon, nevertheless, the same was immediately complied with. Later on, the establishment strictly following the procedure for dissolving the legislature, as laid down by the Constitution managed dissolution of the Parliament, resignation of the President and removal of the Prime Minister albeit through forceful means and under duress. As a consequence the Prime Minister dismissed himself by using his constitutional authority advising the President to dissolve the Parliament and after having acted upon the advice of the Prime Minister, the President resigned his post prima facie for personal reasons but to fulfill the agreement accepted by him and Nawaz Sharif under duress.

Farooq Leghari and Benazir Bhutto succeeded Ishaq Khan and Nawaz Sharif as President and Prime Minister respectively. Farooq Leghari was a stalwart and active member of Benazir's PPP hence it was logically anticipated that there would be quite smooth running with cordial and cooperative relationship between the Prime Minister house and the presidency, nevertheless the second term of Benazir Bhutto (1993-96) came to an end with her dismissal by none else but President Farooq Leghari.

\subsection{Nawaz Sharif Enters his $2^{\text {nd }}$ Term}

Caretaker government was appointed and date was fixed for polling. Initially President Leghari, remained neutral but the incessant attacks from Benazir subsequently forced him to enter into a secret deal with Nawaz Sharif. With the co-operation of the establishment, the President made significant concessions to Nawaz enabling him to contest and win the elections. To accommodate Mian Brothers, Ineligibility Rules regarding the participation of the loan defaulters in the elections were framed in such a way which suited them. Fakhruddin G. Ibrahim, the Federal Law Minister in caretaker government resigned after stating publicly that the President had joined hands with Nawaz to bring him to power (Khan, 2009: 445). The elections were held in February 1997 with remarkably low turnout. The PML (N) obtained absolute majority in the National Assembly, an overwhelming majority in Punjab, emerged as the $2^{\text {nd }}$ largest party in NWFP (now Khyber Pakhtunkhwa) whereas in the Provincial Assemblies of Sindh and Balochistan no party emerged with clear majority.

\subsection{Confrontation with Judiciary}

Nevertheless Chief Justice Sajjad Ali Shah had paved the way for Nawaz Sharif's second term as Prime Minister but the differences between the two arose soon. The event started when the Chief justice took suo moto notice of handcuffing the senior government officials by the Prime Minister and set them free on bail. The opposition of the Chief justice to the enforcement of Anti-Terroirst Law further deepened the gulf between the two. Moreover the names of five judges to be elevated to the Supreme Court were sent by the Chief Justice to the Prime Minister, which was in accordance with the procedure for appointment of the judges as laid down by the judgment in the Al-Jehad Trust case (Note 12). Owing to his personal concern over the names of the two among the said five, the Prime Minister resisted to act upon the recommendations. Various tactics were used and alternative proposals were 
floated by the Prime Minister to escape acting upon the recommendations, but when the President intervened, the government had to notify the said appointments.

\subsection{The Contempt of Court Case}

In October 1997, the Supreme Court of Pakistan suspended the $14^{\text {th }}$ Constitutional Amendment. During a press conference, Nawaz Sharif, vehemently criticized the said suspension and declared the same as illegal and unconstitutional, which resulted in the 'contempt of court' proceedings against him. The Prime Minister had to appear before the Court twice but in his written statement, he just expressed his regret over his remarks, which failed to satisfy the Court. To facilitate the Prime Minister, the Parliament legislated on the issue of contempt proceedings, but President Leghari refused to accord his assent to the said legislation on the ground that he would do the needful provided the Supreme Court didn't prevent him. The Supreme Court picked the hint and while ruling over an application filed on the same issue, restrained the President from signing the Bill.

It was in the notice of the government that the majority of the judges of the Supreme Court were annoyed because of the autocratic style of Chief Justice Sajjad Ali Shah. In Quetta and Peshawar Registries, appointment of Sajjad Ali Shah as Chief Justice of Pakistan, was challenged being in contravention with the judgment of the Supreme Court in Al-Jehad Trust Case. It was believed by some analysts that the Federal Government was involved in the said litigation. Meanwhile the contempt proceedings against the Prime Minister, earlier suspended by the Supreme Court on the request of the military command, were resumed. Reacting to the situation, the PML (N) workers including parliamentarians stormed the Supreme Court building and made it impossible for the judges to continue the hearings. Under the circumstances, the Chief Justice was left with no option but to request the President for the provision of security who forwarded the same to the Prime Minister who ignored it. The Chief Justice then tendered the same request to the Chief of the Army Staff. Meanwhile a double bench of the Quetta Registry passed an order restraining Justice Sajjad Ali Shah to perform in the capacity of the Chief Justice while after almost identical proceedings similar order was passed by the Peshawar Registry of the Supreme Court. Subsequently the seniority issue was dealt with by the Supreme Court at its Principal seat in Islamabad where after lengthy proceedings, Justice Sajjad Shah had to vacate the office. Justice Ajmal Mian, the senior most judge of the Supreme Court, was appointed as the new Chief Justice of Pakistan. Meanwhile when the seniority case was still under process in the Supreme Court, President Leghari who was siding Justice Sajjad Ali Shah against the government had also to resign. His resignation brought to an end the conflict between the judiciary, the executive and the legislature.

\subsection{Confrontation with Army}

In the beginning of the second term, Nawaz Sharif was advised by the New York Times, in a leading editorial, that he had to eliminate the uncommon influence of military establishment, clerics and feudal landlords in making of public policy (Ziring, 1998: 601) so after having dealt with the judiciary, the military was on the top of his agenda. In October, 1998, while addressing in Naval War College, General Jehangir Kramat, the then Chief of the Army Staff, proposed that a National Security Council be established for dealing with important national issues. As a consequence he was forced out of his office and succeeded by General Parvaiz Musharraf. After this replacement, media painted Nawaz Sharif as the most powerful Prime Minister in the history of Pakistan as he had succeeded in curtailing the powers of the President through Thirteenth Amendment to the Constitution, rationalized the Parliament through Fourteenth Amendment, forced the President to resign, driven out a Chief Justice from his office and most significant of all sacked the Chief of the Army Staff (Khan, 2009: 472) who in the previous history of Pakistan captured the most powerful position in the establishment and remained always on the delivering end.

As a positive gesture to normalize the relations between the two countries, Nawaz Sharif invited Mr. Vajpayee, Prime Minister of India, to visit Lahore. Nevertheless, this process of normalization was hampered by the Kargil war, where the Indian Army was badly trapped by the Mujahideens supposedly supported by Pakistan Army. The stance of the Pakistan Government over the issue couldn't fetch approval of the international community. Owing to international pressure, Nawaz Sharif had to fly to Washington and sign a unilateral accord with USA without Indian participation to the effect of withdrawal of his forces from Kargil. Accordingly Pakistan Army had to withdraw from Kargil in extremely humiliating and disgusting circumstances. As a natural consequence Nawaz-Army relations became extremely tense. Rumors about sacking of another Army Chief by Nawaz Sharif were in the air (Note 13).

On October 12, 1999, while General Musharraff was on his way back from an official tour to Sri Lanka, Nawaz Sharif appointed General Ziauddin But (who was reportedly related to Nawaz family) as the new Army Chief which appointment was resisted by the Army Corps Commanders. The television screens on that evening displayed the new appointment for a while but soon got interrupted and went blank for a few hours, while after 
resumption the public was informed that Mian Mohammad Nawaz Sharif was sacked by the Army Chief who would address the nation shortly. The new regime alleged that the plane carrying General Musharraf aboard was not allowed by the Nawaz Government to land anywhere in Pakistan, the pilot was rather directed to land outside Pakistan either somewhere in Gulf States or in India. Owing to the acute shortage of fuel, the pilot refused to comply with the direction hence the plane was diverted to Nawabshah. Meanwhile the Army had taken over the control of Karachi Airport and the plane was redirected to land at Karachi.

\subsection{Military Takeover of 1999 by General Parvaiz Musharraf}

On October 12, 1999, General Parvaiz Musharraf, Chairman Joint Chiefs of Staff Committee and Chief of the Army Staff, suspended the Constitution of 1973, dismissed the government of Mian Mohammad Nawaz Sharif and dissolved the National and Provincial Assemblies. In the beginning, the new regime did not require the judges of the Superior Courts to take fresh oath. The Provisional Constitutional Order (PCO) 1 of 1999 only curtailed the writ jurisdiction of the Superior Courts against any act or order of the Chief Executive or any person exercising powers or jurisdiction under his authority (Note 14). However the Oath of Office (Judges) Order, 1999, promulgated on December $31^{\text {st }}$, 1999, required the judges to take fresh oath as specified under the Constitution of Pakistan; but when the various petitions challenging the take over of 1999 were admitted by the Court, a new order called Oath of Office (Judges) Order, 2000, was promulgated. The new order required the judges to take fresh oath in amended form wherein they were made bound to perform in accordance with the Proclamation of Emergency of October $14^{\text {th }}, 1999$, and the PCO. Saeeduzzaman Siddiqui, the then Chief Justice of Pakistan and five other judges of the Supreme Court refused to take the fresh oath. Those judges who took fresh oath were allowed to retain their offices whereas those who refused or were not offered oath had to quit. Justice Irshad Hassan Khan, being the senior most among the remaining judges was appointed Chief Justice of Pakistan. Seven judges of various High Courts were not offered fresh oath while no judge of the High Court refused to take fresh oath.

\subsection{Judgment in Zafar Ali Shah Case}

Syed Zafar Ali Shah, a member of the ousted National Assembly filed a writ petition in the Supreme Court challenging the validity of the act taken by General Parvaiz Musharraf on Oct 12 . The petition was heard by a twelve-judge bench of the Court, headed by Irshad Hassan Khan (Chief Justice). He wrote the judgment while all other judges including Justice Iftikhar Muhammad Choudhry (Chief Justice of the Supreme Court of Pakistan 2011) endorsed without adding separate notes of their own. The Court held that the step taken by General Parvaiz Musharraf was valid as the same was motivated by the doctrine of State necessity.

\subsubsection{Judgment}

The learned Chief Justice examined the circumstances which preceded the military take over of Oct 12, 1999. He was informed by the Attorney-General that on the said date, the ousted Prime Minister issued an illegal order to the effect of retiring General Musharraf, the COAS, and nominating General Ziauddin But as his successor; hence attempted to create dissension among the Armed Forces and threaten the integrity and sovereignty of the country. Moreover, he attempted to hijack the Flight PK-805 carrying on board General Musharraf and 197 persons, through a criminal conspiracy, with the connivance of his associates and co-conspirators at Karachi and Islamabad.

The learned Attorney-General also alleged that the former Prime Minister and his chosen few indulged in corruption, plundered the national wealth amassing their personal wealth through engineering bank defaults of Rs. 365 billion and, which destroyed the national economy. The scale of corrupt practices was so massive that the ordinary functioning of the government in accordance with the provision of the Constitution and the law had lost its meanings. The government was being run contrary to the provisions of the Constitution and there were massive and widespread violations of the Constitution and the law, As a consequence, the former government lost public faith and its constitutional/moral authority stood completely eroded which culminated in the creation of somewhat similar situation to that prevalent in the country at July, 1977. The Attorney-General concluded that in those circumstances the Armed Forces were compelled to move in as the last resort to prevent further destabilization, to cleanse the system and ultimately restore true democracy.

The Attorney-General pleaded that the former government was suffering from lack of transparency and accountability. There were serious allegations of corruption, nepotism, against it and that where there was corruption, there was no good government. The learned Chief Justice endorsed this contention of the Attorney-General and remarked that corruption by itself was a ground for imposition of Martial Law or Proclamation of Emergencies. He upheld the Federation's view that the democratic institutions under the previous government were not functioning in accordance with the Constitution and had become privy to the one man rule and the very purpose for their establishment stood defeated through their conduct. The learned Chief Justice also upheld the allegation that the former Prime Minister was involved in politicizing and destabilizing the Army, and 
created dissensions within its ranks. He remarked that the success of the plan of Oct 12 would have been much more disastrous for both the Armed Forces and the country.

After the Attorney-General had concluded his arguments, the learned Chief Justice, while explaining the nature and application of the law of State necessity ruled that only the Superior Courts could decide whether any given extra-ordinary circumstances had warranted the application of the above doctrine. He referred to his own judgment in the case of Liaqat Hussain (Note 15) in which he had briefly summarized all the prerequisites for the attraction of the said doctrine as laid down earlier by the Court in Nusrat Bhutto case. He held that the said elements included inevitable necessity, exceptional circumstances, no other remedy to apply, measures taken and level of necessity needed to be proportionate etc.

He remarked that all the said elements were present on $12^{\text {th }}$ of Oct, 1999 as the machinery of the government both at the federal and provincial levels had completely broken down which had rendered the Constitution unworkable. In the circumstances when the Constitution could not provide any solution, the action taken by the Armed Forces was dictated by the highest considerations of State necessity and welfare of the people. They intervened to protect the integrity and sovereignty of the county, save it from further chaos, maintain peace, order, economic stability, justice and good governance. He noted that in the instant case the Court already had passed the short order and given de jure status to the regime which took over on October 12, 1999.

He ruled that the action of Oct 12, 1999, was qualified for validation on the ground of State necessity/survival.

Mr. Khalid Anwar a renowned lawyer and Law Minister in the ousted cabinet submitted that since the doctrine of State necessity had been buried by the British Courts long ago, hence could not be resurrected as done by the Federal Court in Special Reference No. 1 of 1955. The Chief Justice declined to accept that contention ruling that the precedents from foreign jurisprudence though entitled for reverence and respect were not applicable to the facts and circumstances prevailing on Oct 12, 1999.

The Chief Justice noted that the Constitution of 1973 was held in abeyance and the regime had announced that the country was to be run as nearly as possible in accordance with the Constitution. He noted that General Parvaiz Musharraf had proclaimed himself as the Chief Executive of Pakistan and remarked that

"Since particularly, he is performing the functions of the Prime Minister, he holds the position of Chief Executive in the scheme of the Constitution and the criticism on this aspect is uncalled for."(Note 16)

He ruled that notwithstanding the Prime Minister had to act as the Chief Executive of the country under the Constitution of 1973, General Parvaiz Musharraf had validly proclaimed himself as the Chief Executive of Pakistan.

While endorsing to the contention of the Federation that the Chief Executive be accorded the power to amend the Constitution, the learned Chief Justice remarked that the scope of the power to amend the Constitution, to be conferred upon the Chief Executive, could not be wider than that exercised by the Parliament itself. He referred to the judgment of the Court in Mahmood Khan Achakzai case (Note 17) where it was held that the Parliament could not alter the basic features of the Constitution. He ruled that the power to amend the Constitution was conferred upon the Chief Executive and the use of which power would be strictly circumscribed by the limitations set by the Court. He laid down the limitations, which were right in the same line as adopted by the Court in Begum Nusrat Bhutto case. He directed the Chief Executive to bring the changes of constitutional nature only with a motive to achieve his objectives declared through his speeches of $13^{\text {th }}$ and $17^{\text {th }}$ October 1999 . While determining the time-scale for the restoration of the institutions as provided by the Constitution, the Chief Justice noted that as submitted by the Attorney-General, the updating of electoral rolls would take two years and only then it would be possible for the Chief Executive to hold the general elections and put back the country into democratic process. In the light of that argument he fixed a period of three years to do the needful.

\section{Analysis}

If we compare the circumstances leading to the imposition of Martial Law in 1977 and army takeover of 1999 we find that at the both occasions an all powerful (only according to the provisions of the Constitution) Prime Minister was heading the government. Z.A. Bhutto, who was the creator of the 1973 Constitution, assigned all powers to the Prime Minister (himself) leaving only a ceremonial role for the President. Zia through $8^{\text {th }}$ Amendment had curtailed substantial powers of the Prime Minister and shifted it to the President. Nawaz Sharif had to repeal the said Amendment through the $13^{\text {th }}$ Amendment to bring back all powers for the Prime Minister (himself) again leaving only a ceremonial role for the President. Bhutto was a seasoned politician and before assuming the office of the President/Prime Minister had become very well acquainted with the ministerial job as Foreign Minister 
under Ayub Khan. Thus having obtained skills for statesmanship, he had privilege over Nawaz who was quite alien to the art of state-craft when he became the Chief Minister of Punjab in 1988 and Prime Minister in 1990 and 1997. Moreover Bhutto came into power after the debacle of East Pakistan in 1971. At that juncture the civil-military bureaucracy coalition, which occupied the position of the most powerful and significant stake-holder of state affairs in Pakistan since 1947, had become demoralized. Their extra constitutional role in politics was strongly condemned by the intelligentsia, writers, analysts and public at large and declared as the major cause for the dismemberment of Pakistan. Logically the tired and beaten horse of the civil-military bureaucracy was not in a position to assert and resume its role immediately which provided Bhutto a considerable space to breathe and establish as a person to deliver. On intellectual level, there was no match of Bhutto in civil bureaucracy hence he very soon brought them under his command and they behaved like tamed horse for a while albeit unhappily; whereas when Nawaz Sharif became the Prime Minister in 1997, civil-military bureaucracy coalition had again captured the driving seat since 1977 and had established its role through a powerful President as their representative in a system which allowed only a controlled/guided democracy with "rationalized" institutions.

One thing common and identical in the Martial Law of 1977 and military takeover of 1999 is that at both the occasions an "all powerful" Prime Minister was removed by the establishment through military bureaucracy because in the forthcoming days a powerful Parliament and Prime Minister did not suit the designs of the establishment and the agencies and was also not congenial for the USA to use Pakistan as front-line state and a strategic base to achieve their targets in Central and South Asia. Bhutto's ouster from power preceded the soviet occupation of Afghanistan in 1979. At that juncture the role played by Pakistan as front-line state provides strong and valid evidence for the above contention. Similarly the dismissal of the Nawaz Sharif's government by General Musharraf also coincided with the American occupation of Afghanistan in the beginning of the $21^{\text {st }}$ century when again Pakistan not only played the role of a front-line state but has become the battle-field and victim as well. In November 2011, the NATO forces hit two Pakistani Posts in the Mehmand Agency and killed 24 troops leaving many other injured. Moreover Bhutto and Nawaz both had become intolerable for the establishment due to their autocratic, egoistic and snobbish behavior, whereas the establishment in Pakistan always feel comfortable with yes-man Prime Minister and the moment he/she tries to violate the rules of the game is removed. Khwaja Nazimuddin (1953), Mohammad Ali Bogra (1954), Hussain Shaheed Suharwardi (1957), Z.A. Bhutto (1977), Mohammad Khan Junejo (1988), Benazir Bhutto (1990), Nawaz Sharif (1999) are examples.

In the two cases some circumstances were dissimilar. Dismissal of Z.A. Bhutto was preceded by a country wide agitation launched and patronized by the political parties opposing Bhutto on account of allegedly rigged general elections. Irrespective of the fact that an agreement between him and the opposition parties had been finalized and was to be signed very shortly (Note 18); the army-men moved, dismissed and captured Bhutto because the patch-up and cease-fire between them was not acceptable to the establishment and local or international agencies. It is worth mentioning that in response to the demand of the opposition parties Bhutto had agreed to the withdrawal of the Armed Forces from Balochistan and release of Khan Abdul Wali Khan (Chief of the National Awami Party) and his associates from Hyderabad jail where they were being tried for alleged conspiracy leading to treason. It was reported that General Ziaul Haq, the then COAS, walked out of the meeting room and jeopardized the forthcoming agreement. It is surprisingly interesting that, just after the imposition of Martial Law, Zia withdrew the Armed Forces from Balochistan as well as released Wali Khan and others. The analysis and observation offered by Professor Lawrence Ziring cited and quoted above also supports the contention that the civil and military bureaucracy had already (1976) become impatient and intolerant towards Bhutto and had decided not to allow him to continue. In 1999 again the establishment had become impatient and intolerant towards an all powerful Prime Minister Mian Mohammad Nawaz Sharif who had kept a COAS(General Asif Nawaz Janjua) under pressure till he died, sacked another COAS(General Jehangir Karamat) through obtaining his resignation and finally had attempted to sack yet another COAS(General Parvaiz Musharraf) and replace him by General Ziauddin after having a raw with the former over the mis-adventure and consequent humiliation at Kargil. But General Parvaiz Musharraf retaliated promptly, sacked him and took over the administration of the country without imposing Martial Law.

If we examine the verdict in the two cases i.e. The Nusrat Bhutto and Zafar Ali Shah, we find almost similar rulings of the Court. In 1977 the Martial law was imposed and Bhutto was sacked for maladministration, corruption, nepotism and allegedly rigged elections of March 1977 which had triggered a large scale protest and agitation creating a very serious condition of law and order thus rendering the then existing Constitution non-operational and unworkable. The situation on October 12, 1999, was altogether different than that on or before July $5^{\text {th }} 1977$. Nawaz Sharif was sacked on the charges of maladministration, corruption, nepotism and mismanagement of the national wealth combined with the attempt to disrupt the unity and discipline of the Armed Forces. As far as the 
charges of corruption were concerned, it was a progressive and continuous factor which could not be considered as an immediate cause to provide justification for resorting to the extra-constitutional step of that gravity. In fact this was the outcome of quite a long tussle between a Prime Minister having concentrated all constitutional powers in his hands and the Armed Forces which were eager to assert and play their extra-constitutional role as usual.

It is interesting to note that the Supreme Court placed both the cases on the same shelf and level. The Court validated the extra-constitutional step taken by the Armed Forces in both the instances applying the law of State necessity. General Zia (1977) and General Musharraf (1999) both were accorded the power to make laws and amend the Constitution. In Nusrat Bhutto case no time limit was fixed by the Court for the Martial Law authorities to complete the process of accountability and holding fresh general elections whereas in Zafar Ali Shah case the Court fixed a period of three years which is considerably a long spell to undo/check the corruption and hold fresh general elections.

It appears that in both the cases the Court had no other consideration and intention but to validate the extra-constitutional step taken by the Armed Forces on one pretext or the other thus allowing them to rule for long periods of eleven and nine years respectively. During these periods, the growth of a responsible government in the country was hampered; the Constitution was not allowed to work while the institutions were refrained to perform their respective functions (Note 19).

Again in 2011, the enactment of the $18^{\text {th }}$ Amendment in the Constitution has established supremacy of the Parliament with an all powerful Prime Minister. There is a growing tension and quite uncomfortable relationship between the civil and military leadership. Prime Minister Syed Yousaf Raza Gillani and COAS General Ashfaq Parvaiz Kiani seem to be in the mid of cold war. The memo-gate issue resulting in the sacking of Hussain Haqqani, Pakistan's Ambassador to US through his resignation has brought the civil-military relationship again to a boiling point (Note 20).

The prevailing tension among the civil military leadership indicates that the same does not suit the other stake-holders of the state which further supports the argument and contention of this study. During hearing of the petitions filed by Nawaz Sharif and others over the memo scandal, the Supreme Court was informed that after US raid of May 2, 2011, on Usama Bin Laden's compound in Abbotabad, an impression was created that the army wanted to takeover (Note 21).

By virtue of the $18^{\text {th }}$ Amendment, the President (Asif Ali Zardari) is left with a ceremonial role and the Prime Minister (Yousaf Raza Gillani) enjoys substantial powers. They belong to the same political party (Pakistan Peoples Party) wherein the President as the head of the party is able to play an assertive role keeping the Prime Minister under his command. In this situation the non-state actors have the opportunity to get the needful done by a single person i.e. the President which is easily endorsed and owned by the Prime Minister, the Cabinet and the Parliament. But in the future when these two positions go to persons belonging to different political parties, there is a very big question mark that how the establishment would deal with a powerful Prime Minister like Bhutto (1977) and Nawaz Sharif (1999)? Would they again resort to the extra-constitutional step to unseat such an all powerful Prime Minister? These questions need to be answered and the correct answer shall be provided by the future events only.

At present, the role played by the Supreme Court of Pakistan is quite positive and supportive for the working of the Constitution and respective institutions of the country. At the time when this study is being finalized (end December 2011) Justice Iftikhar Mohammad Choudhary, Chief Justice of the Supreme Court of Pakistan and all other judges of the higher judiciary have time and again endorsed the contention of the study that the validation of the extra-constitutional steps taken by the Armed Forces was unjustified, uncalled for and detrimental to the constitutional and political development of the country.

Justice Iftikhar Mohammad Choudhary, during a conversation with delegation of National Defense University at the Supreme Court building, reiterated that

"any action of the armed forces taken without a direction by the federal government will be unconstitutional, illegal, void ab initio and consequently of no legal effect.” (Note 22)

Again while hearing the petitions over the memo scandal Justice Choudhary has categorically warned the Armed Forces that the Higher Courts including the Apex Court would not validate any extra-constitutional step taken by them and would not allow anyone to disrupt the working of the Constitution and the respective institutions (Note 23). He added that

"the (amended) code of conduct demands the judges to preserve and protect the constitution at all cost. The system will run according to what the constitution demands."(Note 24) 
But keeping in view the previous role of the judiciary at such occasions, it shall be premature to precisely predict that what is in the store for the country in the near and distant future. It cannot be said as sure that in the instance of a military takeover in future, the judges of the higher judiciary shall resist or succumb to the pressure and validate the said extra-constitutional step.

\section{References}

Al-Jehad Trust vs. Federation of Pakistan 1996 PLD 324 (SC).

Begum Nusrat Bhutto vs. Chief of the Army Staff and Federation of Pakistan 1977 PLD 657 (SC).

Hussain, F. A. (1989). The Problems of Federalism and Regional Autonomy in Pakistan. (Unpublished M. Phil. Thesis). The London School of Economics \& Political Science, London, United Kingdom.

Khan, H. (2009). Constitutional and Political History of Pakistan. $2^{\text {nd }}$ Edition. Karachi: Oxford University Press. Mehmood Khan Achakzai vs Federation of Pakistan 1997 PLD 426 (SC).

Mian Muhammad Nawaz Sharif vs. Federation of Pakistan 1993 PLD 473 (SC).

Miss Asma Jilani vs Government of the Punjab 1972 PLD 139 (SC).

Newberg, P. R. (1995). Judging the state-Courts and constitutional politics in Pakistan. New Delhi: Foundation Books. http://dx.doi.org/10.1017/CBO9780511563362

Reference by His Excellency The Governor General 1955 PLD 435 (FC).

State vs. Dosso 1958 PLD 533 (SC).

Syed Zafar Ali Shah vs. General Parvaiz Musharraf 2000 PLD 869 (SC).

Ziring, L. (1998). Pakistan in the Twentieth Century. $2^{\text {nd }}$ Impression. Karachi: Oxford University Press.

\section{Notes}

Note 1. However no writ jurisdiction was available against CMLA or any MLA or any person acting on their authority. (See Khan, 2009: 342)

Note 2. The Sun, Lahore, $23^{\text {rd }}$ September 1977 reported about the issuance of CMLA's Order No.6 of 1977(5 $5^{\text {th }}$ amendment) to CMLA (Order No. 1) of 1977 having the effect as if Articles 179, 195, 199 had not been amended.

Note 3. "Requiring all High Court judges to take oath in the form set out in the schedule thereof where significant and material alterations were made particularly the entire sentence "That I will preserve, protect, and defend the Constitution of the Islamic Republic of Pakistan” was totally omitted”. (See Khan, 2009: 342)

Note 4. The Sun, Lahore, 24 September 1977 reported that ten Judges of the Lahore High Court took oath in pursuance of the said Order.

Note 5. Supreme Court Judges (Oath of Office) Order 1977. The Sun, Lahore, 24 September 1977 reported about the oath taken by Anwar-ul-Haq and other Judges of the Superior Courts. As quoted by the newspaper, the amended oath read as:

"That, as the Chief Justice (or a Judge) of the Supreme Court of Pakistan, I will discharge my duties, and perform my functions, honestly, to the best of my ability and faithfully in accordance with the law:

That I will abide by the code of conduct issued by the Supreme Judicial Council:

That I will not allow my personal interests to influence my official conduct or my official decisions:

And that, in all circumstances, I will do right to all manner of people, according to law, without fear or favour, affection or ill-will.”

It had no mention of the Constitution of the Islamic Republic of Pakistan. Compare from original oath in THE CONSTITUTION OF ISLAMIC REPUBLIC OF PAKISTAN [AS AMENDED UPTO $1^{\text {ST }}$ FEBRUARY, 1989], Lahore: P.L.D. Publishers. p184.

Note 6. The Sun, Lahore, 2 October 1977, reported that October 18 polls had been postponed by CMLA till such time the process of accountability was completed.

Note 7. State vs. Dosso 1958 PLD 533 (SC). Here the Martial Law of 1958 was validated by Chief Justice Mohammad Munir. (See also Newberg, 1995: 162-163). 
Note 8. Reference by His Excellency The Governor General 1955 PLD 435 (FC). Here the Federal Court (later renamed under the Constitution of 1956 as Supreme Court) invoked the doctrine of necessity for the first time in the judicial history of Pakistan.

Note 9. Miss Asma Jilani vs Government of the Punjab 1972 PLD 139 (SC). The Martial Law, imposed by Yahya Khan in 1969, was declared illegal by the Supreme Court.

Note 10. Begum Nusrat Bhutto vs. Chief of the Army Staff and Federation of Pakistan 1977 PLD 703 (SC).

Note 11. Mian Muhammad Nawaz Sharif vs. Federation of Pakistan 1993 PLD 473 (SC).

Note 12. Al-Jehad Trust vs. Federation of Pakistan 1996 PLD 324 (SC). (Also known as Judges Case)

Note 13. According to Press Reports, Lt. General Tariq Parvaiz, Commander 12 Corps, was retired from the army for having privately met with the Prime Minister without informing the Army Chief. On October 9, 1999, Ministry of Defense issued a press release stating that the Lt. General was retired owing to "service reasons" on the recommendation of the Chief of the Army Staff which was approved by the Prime Minister himself who is the competent authority for the approval of all promotions/retirements of Brigadiers/equivalent and above ranks. (See The Dawn, Lahore, 10 Oct 1999)

Note 14. The Dawn, Lahore, 15 October 1999.

Note 15. Liaqat Hussain vs. Federation of Pakistan 1999 PLD 504 (SC).

Note 16. Syed Zafar Ali Shah vs. General Parvaiz Musharraf 2000 PLD 1208 (SC).

Note 17. Mehmood Khan Achakzai vs Federation of Pakistan 1997 PLD 426 (SC).

Note 18. It was revealed by Mufti Mehmood Ahmad (Chief of Jamiat Ulema-e-Islam) and Professor Ghafoor Ahmad (Naib Amir of Jamaat-e-Islami) to the co-author (Fayyaz Ahmad Hussain) in an interview. Both of them were members of the team of PNA negotiating with Bhutto till $4^{\text {th }}$ of July 1977 just one day before the imposition of Martial Law in the country.

Note 19. Paula R. Newburg commented over the judgment in Nusrat Bhutto case as: "Sidestepping methodological pitfalls in earlier constitutional cases, newly appointed Chief Justice Anwar ul Haq issued an opinion giving the military government free rein to hold power as it wished and offering General Zia warrant to retain that power. Nusrat Bhutto's case confirmed a legal foundation for a decade-long military government that made deep inroads into the civil society and orchestrated a legal system that endured well beyond General Zia's death in 1988.” She added that Anwarul Haq while accepting the political unrest in the country as a valid base of the military take over anticipated immeasurable political disruption if the takeover did not take place. He ignored the fact that the PNA agitation had ended several weeks earlier. (See Newberg, 1995:163-164)

Note 20. The Dawn, Lahore, 23 December 2011.

Note 21. The Dawn, Lahore, 24 December 2011.

Note 22. The Dawn, Lahore, 13 November 2011.

Note 23. The Dawn, Lahore, 24 December 2011.

Note 24. The Dawn, Lahore, 24 December 2011.

\section{Authors}

Fayyaz Ahmad Hussai, M. Phil from The London School of Economics \& Political Science (1989) and Former Faculty Member, Department of Political Science \& International Relations, Bahauddin Zakariya University (BZU), Multan, Pakistan. Tel: 92-300-841-4950

Abdul Basit Khan, Lecturer, Department of Political Science \& International Relations, Government College University, Faisalabad, Pakistan. Tel: 92-300-609-0344. E-mail: basitniazi@yahoo.com 